IBAD Sosyal Bilimler Dergisi

IBAD Journal of Social Sciences

dergipark.org.tr/ibad

IBAD, 2021; (9): 462-480

DOI: $10.21733 /$ ibad.846169

Özgün Araştırma / Original Article

\title{
Sosyal Bilgiler Öğretmenlerinin Yapılandırmacı Yaklaşıma Dair Öz Yeterlik Algıları ve Buna Etki Eden Faktörlere İlişkin Görüşleri
}

\section{Self Efficacy Perception of Social Studies Teachers about Constructivism and their Opinion about the Factors Affecting It}

\author{
Mustafa Bada ${ }^{*}$ \\ Cevdet Kırpık ${ }^{2}$ \\ * Sorumlu yazar \\ Corresponding author
}

\author{
${ }^{1}$ Mustafa Bada \\ Öğretmen, Türkiye \\ Teacher, Turkey \\ bada-07@hotmail.com \\ ORCID ID 0000-0002-3198-0406
}

${ }^{2}$ Cevdet Kirpik

Prof. Dr., Erciyes Üniversitesi, Kayseri, Türkiye

Prof. Dr., Erciyes University, Turkey

cevdetk@erciyes.edu.tr.

ORCID ID 0000-0002-2183-1255

Makale geliş tarihi / First received : 24.12.2020

Makale kabul tarihi / Accepted $\quad$ : 10.02.2021

This article was checked by Turnitin. Similarity Index 14\%

\section{Bilgilendirme / Acknowledgement:}

Yazarlar aşağıdaki billgillen dirmeleri yapmaktadırlar:

1- Yazarların katkı oranı eşittir.

2- Bu çalışma, Erciyes Üniversitesi Eğitim Bilimleri Enstitüsü’nde Prof. Dr. Cevdet Kırpık danışmanlığında Mustafa Bada tarafından 2018 yılında hazırlanan “Sosyal Bilgiler Öğretmenlerinin Yapılandırmacı Eğitim Yaklaşımına İlişkin Görüşleri" adlı yüksek lisans tezinden elde edilen veriler temelinde oluşturulmuştur.

3- Araştırmamıza katkısı olan tüm öğretmenlere teşekkür ederiz.

4- Makalenin yazarları arasında çıkar çatışması bulunmamaktadır.

5- Makale verileri 2017- 2018 eğitim öğretim yılında 14 sosyal bilgiler öğretmeni ile görüşmeden elde edilmiştir.

6- Bu makalede araştırma ve yayın etiğine uyulmuştur.

Bada, M., Kırpık, C. (2021). Sosyal bilgiler öğretmenlerinin yapılandırmacı yaklaşıma dair öz yeterlik algıları ve buna etki eden faktörlere ilişkin görüşleri. IBAD Sosyal Bilimler Dergisi, (9), 462-480. 
ÖZ

Sosyal bilgiler bireylerin kendisini ve çevresini tanıyarak topluma adapte olmasını sağlayan bir disiplindir. Yapılandırmacılık ise öğrenilen bilgilerin, deneyimlerin üzerine inşa edilmesini amaçlayan bir yaklaşımdır. 2005-2006 eğitim öğretim yılından itibaren sosyal bilgiler öğretim programında yapılandırmacı anlayış benimsenmiştir. Bu araştırmanın amacı; sosyal bilgiler öğretmenlerinin yapılandırmacı yaklaşımı uygulamaya yönelik öz yeterlik algılarını ve bu algıları etkileyen durumları tespit etmektir. Araştırmanın çalışma grubu, Türkiye Cumhuriyeti Milli Eğitim Bakanlığına bağlı Kayseri ilinde görev yapan 14 sosyal bilgiler öğretmenidir. Araştırmada nitel araştırma yöntemi kullanılmıştır. Veri elde etmek amacıyla nitel araştırma tekniklerinden yarı yapılandırılmış görüşme formu hazırlanmış ve sosyal bilgiler öğretmenleriyle görüşmeler yapılmıştır. Örneklem seçimi için ise amaçlı örnekleme yöntemlerinden kolay ulaşılabilir durum örneklemesi kullanılmıştır. Verilerin yorumlanmasında kuramsal anlamda çok açık kuramsal temele sahip olan araştırmalarda kullanılan betimsel analiz yöntemi kullanılmıştır. Araştırmadan elde edilen verilere bakıldığında sosyal bilgiler öğretmenlerinin genel olarak yapılandırmacı anlayış konusunda kendilerini yeterli görmedikleri anlaşılmıştır. Ayrıca sosyal bilgiler öğretmenlerinin üniversitede çoğunlukla teorik eğitim aldıkları, uygulamalı etkinliklere yeterince yer verilmediği, staj eğitimlerinin yetersiz olduğu, deneyimli öğretmenlerin bu anlayıştan uzak olduğu, deneyimsiz öğretmenlerin ise farklı iş yükleri nedeniyle bu anlayışı uygulamaya vakit bulamadıkları, hizmet içi eğitimlerin amaca uygun olmayıp niteliksiz olduğu sonucu ortaya çıkmıştır.

\section{Anahtar kelimeler}

sosyal bilgiler öğretmen görüşü, uygulama düzeyi, öz yeterlik, yapılandırmacılık
ABSTRACT

Social studies is a discipline that enables individuals to adapt to society by recognizing themselves and their environment. Constructivism is an approach that aims to build on the knowledge and experience gained. The constructivist approach has been adopted in the social sciences curriculum since the 2005-2006 academic year. The purpose of this research is to determine the selfefficacy perception of social studies teachers and the situations affecting these perceptions in applying the constructivist approach. The studying research group is the 14 social sciences teachers serving at the ministry of the Turkish Republic National Education in the Kayseri. In this study, the qualitative method of research has been used. In order to obtain the data, a semi-structured interview form of the techniques of qualitative research has been prepared and interviews are performed with the social sciences teachers. A convenience sample, which is one of the purposive sampling methods, is used for the selection of the sample. In addition, the method of descriptive analysis is discussed in the interpretation of the data. When the obtained data are analyzed, it has been concluded that social studies teachers are generally insufficient in the matter of the constructivist approach. Furthermore, the consequences demonstrated that social studies teachers mostly receive theoretical education at universities, applied education is not given enough attention and insufficient internship opportunities. In addition, it is revealed that the experienced teachers are beyond this approach, inexperienced teachers cannot get around to perform this approach because of different workloads, and in-service training is not suitable for the purpose and not qualified.

\section{Keywords}

social studies teacher's view, practice level, self-efficacy, constructivism. 


\section{GíRIŞ}

Sosyal bilgiler kavramı, insan ve onun sosyal çevresi ile ilişkisini inceleyen bir alandır. Sosyal bilgiler dersinde öğrenciler hem kendi toplumuna ait değerleri öğrenirken hem de başka millet ve toplumlara ait olan değerleri öğrenmekte ve kendisini değişen şartlara adapte etmektedir. Kısacası sosyal bilgiler kültürel mirası ve onun süregelen özelliklerini ele alır (Sağlamer, 1983, s. 6-7). Bu şekilde bireylerin topluma uyum sağlaması ve onun toplumun bir parçası haline gelebilmesi amaçlanmaktadır. Ancak kendi değerlerini bilen bireyler toplumun bir üyesi olur ve sosyal problemlerini çözebilir.

Sosyal bilgiler insanın ruhunu, ahlakını ve değerlerini düzene sokan, bireylerin eğitimi açısından son derece faydalı bir alandır. Ayrıca bu derste bireylerin özgürlüklerinin sınırları belirlenmekte, demokrasi, birlikte yaşam gibi kavramlar öğretilmektedir. Bu şekilde bireylerin devletine bağlılığı ve vatan sevgisi aşılanmaya çalışılmaktadır. Bireylerin iyi bir şekilde terbiye görmesi ve ahlaki terbiyenin kazandırılması bu dersin en önemli amaçları arasındadır (Bahar, 2007, s. 48). Sosyal bilgiler bir toplumda yaşayan bireyin, o toplumla yaşayışını, ilişkilerini, kültürünü, dünya milletleri arasındaki yerlerini ve çeşitli milletlerle ilişkilerini esas alan bir disiplindir (Kısakürek, 1988, s. 5).

Sosyal bilgiler dersinin bir amacı da bireylerin toplumsal sorunlarla baş etmesini sağlamaktır. Küreselleşen dünyada, insanların çevresine uyum sağlayabilmesi, demokratik nitelikler kazanabilmesi, becerili, düşünebilen etkin vatandaşlar yetiştirilmesi, sosyal bilgiler dersinin en önemli çalışma alanlarıdır (Doğanay, 2002, s. 17).

Yapılandırmacılık, bilginin doğasıyla ilgilenen bir dizi teori temelinde oluşturulmuş olup bilginin insanlar tarafından meydana getirildiği ve onların değerleri ve kültürlerinden etkilendiği inancına dayanır. Bu görüşün aksini savunan davranış̧̧ı yaklaşıma göre ise bilgi, insanın dışında ve onlardan bağımsız olarak oluşur, iyi bir eğitimin amacı daha önce başkaları tarafından oluşturulan kabul edilmiş bir bilgi ve beceriler bütününü öğrencilere aşılamaktır (Scheurman, 1998, s. 6). Türkiye'de uzun yıllar boyunca uygulanan “Davranış̧̧ı Eğitim Kuramı"na göre ödül ve ceza, öğretim sürecindeki en önemli unsurlardır. Bu unsurları kullanarak insanlara ve hatta hayvanlara bile bir takım şeyler öğretilebilir. Bu yaklaşım insan davranışlarını, çevreden gelen uyarıcılara karşı organizma tarafından verilen tepki olarak tanımlamış ve bireyin bu süreçte pasif olduğunu savunmuştur (Aydın, H. 2000, s. 184).

Dünyada özellikle 1960'lı yıllarda eğitim alanında bir anlayış değişikliği yaşanmış ve yapılandırmacılık eğitimin merkezine konmuştur. Yapılandırmacılık, Bruner tarafından eğitim gündemine getirilmesine rağmen aslında temeli çok eski dönemlerde yaşamış Sokrates'e kadar dayanan bir yaklaşımdır. Montessori'nin geleneksel sınıf anlayışı yerine öğrencinin etkin olduğu bir süreci savunması ve Piaget'in sürekli değişim ve yeniliği savunan fikirleri yapılandırmacı anlayışın temellerini oluşturmuştur (Şimşek, 2004, s. 117).

Yapılandırmacı yaklaşıma göre eğitim bir tecrübedir. Öğrenme, deneyimden anlam inşa etmedir ve öğrencilerin ön bilgilerinin üzerine inşa edilir. Esasında burada çok önemli olan husus bilginin doğası ve öğrenenlerin anlamlı bilgiyi nasıl oluşturdukları meselesidir. Konu tarihi olarak Piaget'in bilişsel yapılandırmacılık ve Vygotsy'nin sosyal yapılandırmacılık yaklaşımı arasındaki ayrımdan kaynaklanmaktadır. Bilişsel yapılandırmacılık, bilginin bireysel etkileşim ve çevrenin analizi ile oluşturulduğu ve anlamlı hale getirildiği fikrine dayanmaktadır. Vygotsky'nin yaklaşımına göre bilgi sadece bireysel olarak zihinde oluşmaz, 
daha ziyade öğrenenlerin fikirlerini ve inançlarını inşa ettikleri, yeniden oluşturdukları ve paylaştıkları sosyal bağlamdaki etkileşimlerle ilişkilidir. Burada öğrenci merkezlilik ve deneyim ön plana çıkmaktadır. (Jadallah, 2000, s. 221).

Bireyler pasif olarak bilgiyi alan değil, bilgiyi aktif bir şekilde oluşturan inşa eden konumunda bulunmaktadır. Bireyler tarafından oluşturulan bu bilgi ise ona verilen bilgiden çok daha fazla ve değerlidir. Yapılandırmacı anlayışa gore bilginin kullanılabilirliği doğruluğundan daha önemlidir. Birey açısından bu bilgilerin işlevsel olabilmesi için kullanılabilmesi, başka bir ifade ile günlük yaşama aktarılması gerekmektedir. (Erden ve Akman, 2001, s. 171).

$\mathrm{Bu}$ yaklaşımda bilgiyi ezberletmek, öğretmek, doğrudan vermek değil, öğrencinin bilgiyi kendi çabasıyla öğrenmesi, araştırması ve kafasındaki önbilgilerle ilişkilendirerek bilgiyi kavraması önemlidir (Özden, 2011, s. 55). Akdağ (2009)'a göre; artık bilgiyi doğrudan almak değil, bilgiyi doğru yoldan almak ön plana çıkmıştır. Yapılandırmacı anlayış öğrencinin pasif değil, aktif olmasını savunmaktadır. Yapılandırmacılık bireylerin bilişsel potansiyellerini, hazırbulunuşluklarını ve onların bireysel öğrenme tercihlerini önemseyerek, bilgileri deneyimlerinin üzerine inşa etmelerini sağlayan bir yaklaşımdır (Öztürk ve Mutlu, 2017, s. 383).

Yapılandırmacı yaklaşıma getirilen tanımlara bakıldığında öğrenmenin önceki öğrenmelerin üzerine inşa edildiği ve bunun sağlanması için de uygun öğrenme ortamı ve süreçlerinin hazırlanması gerektiği ön plana çıkmaktadır. Bunun hazırlayıcısı ise öğretmendir. Bu noktada öğretmenin yapılandırmacı yaklaşıma dair bilgi, beceri ve tutumunun ne olduğu önem kazanmaktadır. Bilişsel yapılandırmacılık, öğretmenin, öğrencilerin önceki bilgileri ile herhangi yeni bir konu arasında ilişki kurabilmelerine imkân sağlayan araştırma ve keşfe dayalı bir öğrenme ortamı oluşturması şeklinde yorumlanmıştır. Vygotsky'nin yaklaşımına göre ise öğretmen ve diğer öğrencilerle etkileşim, öğrenme süreçlerinde hayati bir öneme sahiptir. Öğretmenin daha çok öğrencilerin bilgilerini test edebilecekleri ve oluşturabilecekleri sosyal etkileşim esasına dayalı planlama ve rehber olma özelliği vardır (Jadallah, 2000, s. 221). Sınıf, öğrencilerin sorular sorduğu, özgür düşündüğü, birbirleriyle ve öğretmenle etkileşim halinde olduğu bir ortamdır. Bu yaklaşımda öğretmenin rolü, öğrencilere kalıcı öğrenmeler edinmelerinde danışmanlık ve rehberlik yapmaktır (Kumar ve Teotia, 2017, s. 136). Yapılandırmacı anlayışta öğrencilerin sürece aktif bir şekilde dahil edilmesini başka bir ifadeyle bu anlayışın uygulamasının başarılı olmasını sağlayacak kişi öğretmendir (Dilaver ve Tay, 2011, s. 110). Yani artık eskisi gibi öğretmenin anlatıp öğrencinin not aldığ1 ve o notları ezberlediği bir sistem yerine öğretmenin ona rehber olup kendi yolunu bulmasını sağlaması söz konusudur (Özden, 2003, s. 72-73).

Eğitimin en önemli amaçlarından biri öğrencilerin bilgi, beceri, davranış ve değerlerini geliştirmektir. Bunlar öğrencilerin hızla değişen topluma başarılı bir şekilde katılmalarına yardım edecektir. "Hızla değişen toplum" ifadesi, öğrencilerin öğrendikleri bilginin mutlak olmadığını anlamaları için önemli bir yere sahiptir. Okul ve sınıf, çocuklar için çok önemli bir çevredir. Bu nedenle her bir öğretmen öğrencilerin öğrenme şekli ve özelliğinin belirlenmesine yardım etmeli, öğrencilerin anlamlı bir referans çerçevesi geliştirmelerine katkı sağlayacak olan bir ders planının nasıl yapılacağını ve uygulanacağını bilmelidir (Jadallah, 2000, s. 224225). 
Dünyada 1960'lardan itibaren yapılandırmacı yaklaşım lehine oluşan algı değişikliğinin yansımaları Türkiye'de de görülmüştür. Özellikle 2005-2006 eğitim-öğretim yılından itibaren ülkemizde bu anlayış benimsenmiş ve öğretim programlarımız bu yaklaşıma göre güncellenmiştir (Talim Terbiye Kurulu Başkanlığı, 2005). Bir ülkenin benimsemiş olduğu eğitim sistemi ne kadar güçlü bir temele dayanırsa dayansın, o sistemin uygulayıcısı olan öğretmenin üzerinde bir hizmet üretmesi mümkün değildir (Akçamete, 2005, s. 4). Bu bağlamda öğretmenlerin ülkede kabul edilen eğitim yaklaşımını benimsemesi ve bu yaklaşım konusunda kendilerini ne kadar yeterli hissettikleri başka bir deyişle öz yeterlik algısı önemli bir husustur.

Öz yeterlik, bir kişinin bir işe başlamasını, devam ettirmesini ve sonuca ulaşmasını sağlayan inancı ya da insanların belli bir performansa ulaşabilmesini sağlayacak gücü olarak tanımlanabilir (Bandura, 1986, s. 30). Bandura (1986)'ya göre öz yeterlik inancının gelişmesini sağlayan dört temel kaynak; "deneyimler, dolaylı yaşantılar, sözel ikna ve bireylerin fiziksel, duygusal durumu'dur. Bunların en önemli olanının ise deneyimlerdir. Bir konuda yeterli deneyime sahip olunduğunda öz yeterlik inancı yükselir, içsel motivasyon artar, bu durum ise bizim o konuda başarılı olmamızı sağlar. Yaşantılar, eğer bireylerin başarısını artıracak yönde gelişmişse yüksek öz yeterlik algısı, aksi yönde gelişmişse düşük öz yeterlik algısı meydana gelmektedir. Bireylerin kendisine olan güvenini beslemek için başarı duygusunu tatması gerekmektedir. Öz yeterlik konusu bir işi yapmaya yönelmede ve o işi başarıyla sonuçlandırma da büyük öneme sahiptir. Bu konuda algısı yüksek olan kişiler karşılaştıkları problem durumunda daha kolay çözüm yolları üretebilirken, algısı düşük olanlar problemlerin nasıl çözülemeyeceğine odaklanmaktadırlar.

Kişinin bir konuda kendisine yönelik olumlu algısı o konuyla ilgili olan bütün alanlarda özgüvenini pekiştirmesi içsel motivasyonunu, başarısının sosyal çevresi tarafından takdir edilmesi ise dışsal motivasyonunu artıracaktır. Kişi hem içsel dünyası hem de sosyal çevresiyle ayrılamaz bir varlıktır. Burada unutulmaması gereken husus öz yeterlik kavramının kişinin sahip olduğu beceri ve yetenekler değil, bu beceri ve yeteneklere dair inancının olduğudur (Aydın, 2008, s. 10). Öz yeterlik inancı yüksek olan bireyler karşılaştıkları güçlüklere karşı daha fazla emek harcayıp bu güçlüklerle baş etmek için daha fazla sabır gösterirler. (Timur, 2020, s. 2).

Yapılandırmacı yaklaşımın sosyal bilgiler dersinde uygulanmasına öğretmenlerin yaklaşımına, öğrenme ve öğretme süreçlerine etkisine dair yurt dışında ve yurt içinde çeşitli çalışmalar yapılmıştır. Teague (2000) çalışmasında yapılandırmacılık ile geleneksel anlayışı karşılaştırmış, yapılandırmacılık anlayışının en önemli unsurunun öğrencilerin çevreleriyle etkileşim kurarak, bilgileri yapılandırdığı sonucunu elde etmiştir. Jancic ve Hus (2017) yapmış oldukları çalışmada sosyal bilgiler öğretmenlerinin derslerinde yapılandırmacı anlayışı uygulama konusunda kıdem, meslek unvanı ve öğretilen sınıflar arasında herhangi bir anlamlı farklılık görülmediği, öğretmenlerin rolünün eskiye oranla azalmadığı, bununla birlikte öğretmenlerin daha çok geleneksel yöntemleri kullanmaya devam ettikleri sonucuna ulaşmışlardır.

Kumar ve Teotia (2017) yapmış oldukları çalışmada yapılandırmacı anlayışın hem öğretmenlerde hem de öğrencilerde farklı bir bakış açısı sağladığı, öğrencilerin sınıf ortamına boş sayfa olarak gelmedikleri, öğretmenlerin almış olduğu eğitim, yaklaşım, yöntem ve teknik konusunda esneklik sağlayarak yeni bilgileri öğrencilerin deneyimlerinin üzerine inşa etmesi gerektiği bilgisine ulaşmışlardır. Ayrıca öğretmenlerin bu aşamada başarılı olabilmesi için 
teorik ve uygulamalı çalışmaların dengeli yürütülmesi ve öğretmenlerin yapılandırmacılık konusunda ustalaşmasının önemli olduğunu belirtmişlerdir. Kumar (2019), yapmış olduğu çalışmada öğrencilerin eğitim sürecine katılımında öğretmenin öğrencilere yaklaşımının önemli olduğu, öğrencilerin sorgulamalarına izin verildiğinde öğrencilerde yaratıcılık becerilerinin geliştiği otoriter bir yaklaşımda olunduğunda ise öğrencilerin yaratıcılık becerisinin baltalandığı sonucuna ulaşmıştır. Mohammed, Husam ve Kinyo (2020), yapılandırmacı yaklaşımın birçok ölçme ve değerlendirme aktiviteleri sunan alternatif bir yaklaşım olduğu ve bu anlayışın öğretmenleri klasik görevlerinden uzaklaştırdığı, hem öğretmen hem de öğrencilere seçenekler sunduğu sonucuna varmışlardır.

Ülkemizde 2005-2006 eğitim-öğretim yılından itibaren benimsenen yapılandırmacı yaklaşımın uygulanması konusunda sosyal bilgiler derslerinde bir takım sıkıntılar yaşanmaktadır. Bunlardan biri öğretmenlerin lisans düzeyinde aldıkları eğitim ile hizmet içi eğitimin yetersizliğinden kaynaklandığı söylenebilir. Ay, Ünlü ve Koçoğlu'nun (2015) sosyal bilgiler öğretmenliği programında öğrenim gören öğretmen adaylarıyla yapmış olduğu çalışmada, uygulama derslerinin yetersiz olduğu, teorik derslerin uygulamaya geçirilemediği, öğrencilerin öğrenmelerinin ezberle sınırlı kaldığı sonucuna ulaşmıştır. Özellikle ülkemizde yapılandırmacılıkla ilgili yapılan çalışmalarda sosyal bilgiler öğretmenlerinin, bu anlayış konusunda kendilerini yeterli görmedikleri, ders saatlerinin ve okulun fiziki olanaklarının bu anlayışı uygulamada yetersiz olduğu, programların öğrencilerin ihtiyaçlarını karşılamadığı, bu olumsuzlukların ise yapılandırmacı anlayışın uygulanmasını engellediği tespit edilmiştir (Arslantaş, 2006; Tahiroğlu, 2006; Akdeniz, 2008; Karadağ vd. 2008; Karacaoğlu ve Acar, 2010).

Dünyada eğitim konusunda güncel konularla ve yaklaşımlarla ilgili çalışmalar artmasına rağmen, yapılandırmacılığa ilişkin sosyal bilgiler öğretmenlerinin öz yeterlik algıları Türkiye'deki eğitim çalışmalarında kendisine yeterince yer bulamamıştır. Ülkemizde yapılan çalışmalara bakıldığında YÖK Tez Merkezi'nde Ağustos 2020 tarihi itibariyle sosyal bilgiler alanında yapılandırmacılık konusunda yüksek lisans düzeyinde 12 ve doktora düzeyinde 2 olmak üzere toplam 14 tez yazıldığı görülmektedir. Yapılan bu çalışmaların bir kısmının müfredat bir kısmının ise karşılaşılan sorunlarla ilgili olduğu görülmektedir (Sarıaslan, 2005; Arslantaş, 2006; Aykaç, 2007; Çetin, 2007; Atbaşı, 2007; Başoğlu, 2009; Bulut ve Arslan 2010; Dinç ve Doğan, 2010; Kuş ve Çelikkaya, 2010; Akşit, 2011; Önen, Erdem ve Gürdal, 2011; Yılmaz ve Tepebaş, 2011, Yürüdür, Cımbız, 2017). Ancak sosyal bilgiler öğretmenlerinin yapılandırmacılık konusunda öz yeterlik algıları ve buna etki eden faktörlerle ilgili bir çalışmanın yapılmadığı tespit edilmiştir. Bununla birlikte yapılan çalışmalarda konuya dolaylı da olsa değinen çalışmalar bulunmaktadır (Tahiroğlu, 2006; Aykan, 2014).

Tahiroğlu (2006), "İlköğretim okullarının ikinci kademesinde sosyal bilgiler dersi öğretmenlerinin sosyal bilgiler dersinde karşılaştıkları güçlükler; Aksaray örneği" isimli tez çalışması yapmıştır. Araştırma Aksaray ilinde görev yapan 80 sosyal bilgiler öğretmenine anket şeklinde uygulanmıştır. Araştırma sonucunda öğretmenlerin üniversitede gerekli becerileri tam manasıyla öğrenemedikleri, hizmet içi eğitimlere yeterince katılamadıkları, kendilerini yeterince geliştiremedikleri, araç- gereç temininde zorluklar yaşadıkları, okul çevresinin eğitimi olumsuz etkilediği sonucunu elde etmiştir.

Aykan (2014), "'Ortaokul öğretmenlerinin yapılandırmacı yaklaşım ile ilgili yeterlik düzeylerinin incelenmesi" isimli çalışmasında ortaokulda görev yapan öğretmenlerin yapılandırmacılık 
konusunda kendilerini orta düzeyde yeterli gördüklerini, bunun yanında yaş, cinsiyet, mesleki kıdem, lisansüstü eğitim durumlarının öz yeterlik algılarını etkilediği sonucuna ulaşmıştır.

Öğretmenin pedagojik yeterlikleriyle öz yeterlik algısı arasında kuvvetli bir ilişki olduğundan yeni anlayışın etkili bir şekilde uygulanabilmesi için öğretmenin öz yeterlik algı düzeyinin bilinmesi önemlidir. Bu çalışmada "Sosyal bilgiler öğretmenlerinin yapılandırmacı anlayışa dair öz yeterlik algıları ile buna etki eden faktörler nelerdir?" sorusunun cevabı aranacaktır. Bu kapsamda onların yapılandırmacılıkla ilgili öz yeterlik algılarını etkileme potansiyeli taşıyan lisans düzeyinde aldıkları eğitimin niteliği, kıdeme esas çalışma süreleri ve hizmet içi eğitim faaliyetleri hakkındaki görüşleri analiz edilecektir. Bu araştırmada aşağıda yer alan sorulara yanıt aranmiştır.

1. Sosyal bilgiler öğretmenlerinin yapılandırmacı yaklaşıma yönelik öz yeterliklerine ilişkin görüşleri nelerdir?

2. Sosyal bilgiler öğretmenlerinin yapılandırmacılığa yaklaşımları hakkında öğretmen yetiştiren kurumlara ilişkin görüşleri nelerdir?

3. Meslekte çalışma süresinin yapılandırmacılığa etkisine ilişkin öğretmen görüşleri nelerdir?

4. Sosyal bilgiler öğretmenlerinin yapılandırmacılık kapsamında hizmet içi eğitim faaliyetlerine ilişkin görüşleri nelerdir?

\section{YÖNTEM}

Bu çalışma 2017- 2018 eğitim öğretim yılında 14 sosyal bilgiler öğretmeni ile görüşme yöntemi ile gerçekleştirilen betimsel bir araştırmadır. Öğretmenlere uygulanan yarı yapılandırılmış görüşme formu ile yapılandırmacı anlayışa ilişkin öz yeterlik algılarının ve buna etki eden etmenlerin ortaya çıkarılması ve bu algıların değerlendirilmesi amaçlanmıştır.

\subsection{Katılımcilar}

Çalışmaya katılan öğretmenlerin kıdem yılı, cinsiyet ve görev yeri incelendiğinde öğretmenlerin 7' sinin kadın, 7'sinin erkek olduğu, 7'sinin şehir merkezi, 7'sinin ise köyde çalıştığ1, 10'unun 2-10 yıl, 4'ünün 14 yıl üzeri çalışma süresine sahip olduğu görülmektedir (Tablo 1).

Tablo 1. Araştırmaya Katılan Öğretmenlere Ait Bilgiler

\begin{tabular}{lcccc}
\hline & Kodlama & Cinsiyet & Görev Yeri & Kıdem Yılı \\
\hline 1.Öğretmen & Ö1 & Kadın & Şehir & 14 \\
2.Öğretmen & Ö2 & Kadın & Şehir & 3 \\
3.Öğretmen & Ö3 & Kadın & Köy & 3 \\
4.Öğretmen & Ö4 & Kadın & Şehir & 4 \\
5.Öğretmen & Ö5 & Kadın & Köy & 7 \\
6.Öğretmen & Ö6 & Kadın & Köy & 2 \\
7.Öğretmen & Ö7 & Kadın & Köy & 5 \\
8.Öğretmen & Ö8 & Erkek & Şehir & 27 \\
9.Öğretmen & Ö9 & Erkek & Köy & 25 \\
10.Öğretmen & Ö10 & Erkek & Köy & 10 \\
11.Öğretmen & Ö11 & Erkek & Şehir & 12 \\
\hline
\end{tabular}




\begin{tabular}{lllll}
\hline 12.Öğretmen & Ö12 & Erkek & Köy & 5 \\
13.Öğretmen & Ö13 & Erkek & Şehir & 6 \\
14.Öğretmen & Ö14 & Erkek & Şehir & 9 \\
\hline
\end{tabular}

\subsection{Veri Toplama Aracı}

Katılımcı öğretmenlerin sosyal bilgiler derslerinde yapılandırmacı anlayışın uygulanmasına dair öz yeterlik algısı ve buna etki eden faktörlere ilişkin görüşlerini elde etmeyi amaçlayan bu çalışmada yarı yapılandırılmış görüşme formu kullanılmıştır. Yarı yapılandırılmış görüşme formunda sosyal bilgiler öğretmenlerinin cevaplamaları için 4 adet açık uçlu soru hazırlanmıştır. Açık uçlu soruların avantajı, araştırmacıya incelediği konuyu esnek bir şekilde ele almasını sağlamasıdır (Yıldırım ve Şimşek, 2011). Araştırma sorularının iç tutarlılık geçerliliğini sağlamak için sosyal bilgiler alanında uzman iki kişinin görüşüne başvurulmuştur. Görüşme formuna son şekil verildikten sonra deneme amaçli olarak katılımcılar dışında bir sosyal bilgiler öğretmeniyle görüşme yapılmış, yapılan bu görüşme ses kaydına alındıktan sonra yazıya aktarılmıştır. Ardından alan uzmanıyla yapılan görüşmede, görüşme formu sorularının yeterli olduğu, konuyu yeterli oranda kapsadığı, sorularında anlaşılır olduğu görüldükten sonra görüşme formuna son şekli verilmiştir.

\subsection{Veri Toplama Süreci}

Yarı yapılandırılmış görüşme formu oluşturulduktan sonra Kayseri'de görev yapan katılımcı sosyal bilgiler öğretmenleriyle görüşmeler yapılmıştır. Bu görüşmeler katılımcıya uygun olan yer, zaman ve ders saatlerinin dışında gerçekleştirilmiş, katılımcının rızası alınarak ses kayıt cihazına kaydedildikten sonra yazıya aktarılmıştır.

\subsection{Veri Analizi}

Çalışmada elde edilen verilerin analiz edilmesi sürecinde nitel araştırma yöntemlerinden betimsel analiz yaklaşımı kullanılmıştır. Bu yaklaşım türü dört farklı aşamada gerçekleştirilmektedir. İlk aşamada araştırmacı sorulardan ve bu sorulara almış olduğu yanıtlardan hareket ederek genel bir çerçeve oluşturmaktadır. Bu şekilde elde edilen verilerin hangi temayla ilişkilendireceği belli olur. Daha sonra araştırmacı oluşturmuş olduğu bu çerçeveye göre verileri okuyarak düzenler. Bu bölümde verilerin anlamlı ve mantıklı olacak şekilde bir araya getirilmesi dikkat edilecek önemli bir husustur. Üçüncü aşamada ise elde edilen veriler tanımlanmaya başlanır, gerekli olan bölümlerde doğrudan alıntılara başvurulabilir. Sürecin sonunda ise bulgular açıklanır ve ilişkiler güçlendirilmeye çalışılır. Bunun için de sıklıkla sebep-sonuç ilişkisinin kurulması ve bu ilişkilerin arasında karşılaştırmaların yapılması gerekmektedir (Yıldırım ve Şimşek, 2008, s. 224).

Çalışmada elde edilen veriler öncelikle kodlanmış, ardından temalar belirlenmiş, sonrasında ise kodlar ve temalar arası bağlantı kurularak elde edilen bulgular araştırmacı tarafından yorumlanmıştır. Verilerin analizi bölümünde öğretmenler Ö1, Ö2..., Ö14 şeklinde kodlanmış ve öğretmenlerden elde edilen veriler sinıflandırılarak verilerin frekans dağılımları (f) tablolar aracılığıyla bulgular bölümünde incelenmiştir.

\section{BULGULAR}

Burada öğretmenlerin öz yeterlik alg1sı, üniversite lisans eğitimi ve meslekteki çalışma sürelerinin yapılandırmacı yaklaşıma etkisine ilişkin görüşleri ele alınmıştır. 


\subsection{Sosyal Bilgiler Öğretmenlerinin Yapılandırmacı Yaklaşıma Yönelik Öz Yeterliklerine İlişkin Görüşleri}

Burada sosyal bilgiler öğretmenlerinin yapılandırmacılık konusunda öz yeterliğine ilişkin görüşleri ele alınarak öz yeterlikleri hakkında bilgi edinilmesi amaçlanmıştır. Öğretmenlerin yapılandırmacılık konusunda kendilerini yeterli hissedip hissetmemelerinin yanı sıra neden yeterli veya yetersiz oldukları, kendilerini bu konuda etkileyen durumların neler olduğunun bilinmesinde fayda vardır. Sosyal bilgiler öğretmenlerinin yapılandırmacılık konusunda öz yeterliğine dair görüşleri Tablo 2' de gösterilmiştir.

Tablo 2. Yapılandırmacılık Konusunda Öz Yeterliğe İlişkin Görüşler

\begin{tabular}{lc}
\hline Öğretmen Görüşleri & Frekans \\
\hline Tam manasiyla yeterli hissetmiyorum & 7 \\
Yeterli hissetmiyorum & 5 \\
Yeterli hissediyorum & 2 \\
\hline
\end{tabular}

Tablo 2'ye bakıldığında katılımcılar, yapılandırmacılık konusunda kendilerini tam manasıyla yeterli hissetmediklerini söylemişlerdir. Kendilerini yapılandırmacılık konusunda olumsuz etkileyen nedenleri ifade edip, neler yapmaları gerektiği konusunda da görüş belirtmişlerdir. Katılımcılar yapılandırmacılık anlayışını derslerinde uygulayabilmek için öğretmenin, sürekli güncel kalmasının, yaratıcılık becerisinin gelişmesinin ve etrafında meydana gelen gelişmelere göre kendisini geliştirmesi gerektiğinin önemli olduğunu söylemişlerdir. Bazı katılımcılar çevresel koşulların (veli, izin vs.) kendilerini yapılandırmacılık konusunda olumsuz etkilediğini ve bu yüzden derslerinde yapılandırmacı uygulamalar yapamadığını ifade etmişlerdir. Bunun yanında özellikle mezuniyet tarihi ile şu an içinde bulunduğumuz tarih arasındaki sürenin fazla olmasının, öğretmenlerin değişim ve yenilikleri algılamasını da olumsuz etkilediğini bu durumun ise öğretmenlerin yapılandırmacı faaliyetler yapmalarının önüne geçtiğini belirtmişlerdir. Ayrıca bu katılımcılar yapılandırmacılığı sosyal bilgiler derslerinde daha etkin bir şekilde uygulayabilmek amacıyla daha çok araştırma yapmaları ve bazı durumlarda uzmanlardan yardım almaları gerektiğini belirtmişlerdir. Bu durum aşağıdaki öğretmenlerin görüşlerinde özetlenmiştir:

"Ben hiçbir zaman kendimi donanıml hissetmiyorum. Zaman zaman eksikliklerimizi görüp telafi etmeye çalışıyoruz. Çocuklara her zaman hazırlıkl gelmelerini söylüyoruz. Ama yetersiz kaldığımız oluyor. Araştırma yapıp bilgilerimizin üzerine bilgiler katmamız gerektiğini düşünüyorum." (Ö11)

"Bazı zamanlarda farklı yerlerden yardım almam gerekiyor. Bu bazı internet sitesi, ya da uzman öğretmen arkadaşlar olabiliyor. Onlardan aldığım her destek benim uzmanlaşmamı sağlıyor." (Ö13)

Tablo 2'ye bakıldığında katılımcıların en çok vurguladığı diğer husus ise kendilerini yeterli hissetmemeleridir. Bu katılımcılar, yapılandırmacı anlayışın sürekli kendini yenilemeyi gerektirdiğini, bu nedenle kendilerinin bu duruma ayak uyduramadığını söylemişlerdir. $\mathrm{Bu}$ bağlamda katılımcılar almış oldukları eğitimle şimdiki dönem arasında geçen zamanın kendilerini olumsuz etkilediğini, yapılandırmacı uygulamalar yapamadıklarını ve bilgilerin unutulduğunu ifade etmişlerdir. Bu durumu Ö10 şu şekilde dile getirmiştir: 
"Ben mezun olah 12 sene oldu. 12 yll öncesini düşünürsek tabî̀ ki yeterli görmüyorum çünkü bilgi kendini süreli yeniliyor. Yeni görüss ve yöntemler ortaya çıkıyor. Dolayısıyla yani şu anki ve üniversitede aldığımızı bilgi düzeyinin yeterli olmadığını düşünüyorum." (Ö10)

Tablo 2'ye bakıldığında çarpıcı bir sonuç ise kendisinin yapılandırmacılık konusunda yeterli olduğunu düşünen öğretmen sayısının sadece iki olmasıdır. Kendisini yapılandırmacılık konusunda yeterli hisseden katılımcılar, bu konuda en önemli nedenin öğretmenin kişiliği ve bu anlayışa yatkınlık durumu olduğunu ifade etmişlerdir. Bu bağlamda görüş belirten öğretmenler kendilerinin enerji dolu olduğunu ve yapılandırmacı anlayışı uygulayabilmek için yeterince iyi olduklarını söylemişlerdir. Bu durumu Ö8 aşağıdaki şekilde ifade etmiştir:

"Ben yaş itibari ile artık belli bir yere geldim ama ben sürekli spor yapan bir insanım. Özellikle de öğrencilerimle sürekli ders konusunda aktifim. Hala enerji doluyum. Dolayısıyla da öğrencileri sürece katmak için her şeyi yapabilirim. Kendimi bu konuda yeterli hissediyorum." (Ö8)

\subsection{Sosyal Bilgiler Öğretmenlerinin, Yapılandırmacılığa Yaklaşımları Hakkında Öğretmen Yetiştiren Kurumlara İlişkin Görüşleri}

Araştırmanın bu bölümünde sosyal bilgiler öğretmenlerinin yapılandırmacilık konusunda öğretmen yetiştiren kurumlara ilişkin görüşlerine yer verilmiştir. Öğretmen yetiştiren kurumların yapılandırmacılık konusunda verdiği eğitimin niteliği ve bu eğitimin hangi düzeyde sağlandığı yapılandırmacılığın sosyal bilgiler dersinde uygulanmasında önemli bir konudur. Sosyal bilgiler öğretmenlerinin yapılandırmacılık konusunda öğretmen yetiştiren kurumlara ilişkin görüşleri Tablo 3'te gösterilmiştir.

Tablo 3. Öğretmen Yetiştiren Kurumlara Dair Öğretmen Görüşleri

\begin{tabular}{lc}
\hline Öğretmen Görüşleri & Frekans \\
\hline Teorik eğitim aldık & 12 \\
Uygulamalı etkinlikler kısıtlıydı & 6 \\
Yapılandırmacılık eğitimi almadım & 2 \\
Verilen ve istenen eğitim çelişkiliydi & 2 \\
Yapılandırmacılı̆̆ı sınav döneminde öğrendik & 2 \\
Öğretmenlik uygulaması ve okul deneyimi eğitimi çok yetersiz & 2 \\
\hline
\end{tabular}

Tablo 3 incelendiğinde katılımcıların üniversite de almış oldukları eğitimin niteliğinin dışında, öğretmenlik uygulaması ve okul deneyimi eğitiminden, öğretim elemanlarının yapılandırmacı anlayış hakkındaki faaliyetlerinden bahsettikleri görülmektedir.

Tablo 3'te katılımcı öğretmenlerin en fazla vurguladıkları husus üniversitede teoriye dayalı eğitim almaları konusu olmuştur. Bu bağlamda katılımcılar derslerde verilen eğitimlerin anlatım gibi klasik yöntemlerle kendilerine aktarıldığını, bu durumun ise bilgi düzeyinde öğrenmelerin oluşmasına ve kendilerinde kalıcı öğrenmelerin gerçekleşmesini sağlamadığını ifade etmiştir. Bu konuda Ö12'nin ifadeleri şu şekildedir:

"Aldım ancak teorikte kaldı hep. Üniversitede pratikte bu konunun üzerine pek düşemedik." (Ö12) 
Tablo 3'e bakıldığında katılımcıların en fazla dile getirdiği durumlardan birisi de uygulamalı eğitim konusu olmuştur. Teorik eğitim alan katılımcılardan bazıları, uygulamalı faaliyetler konusunda kısıtlı olarak eğitim aldıklarını ifade etmişlerdir. Katılımcılar, bazı zamanlarda uygulamaların olduğunu ya da uygulamaların öğretim elemanlarına göre değiştiğini söylemişlerdir. Örneğin bu konuda Ö11'in görüşü şu şekildedir:

"Zaman zaman uygulamalar yapıyorduk, sinıfta arkadaşlarla beraber tiyatro yapıyorduk. Konu dağıtıp kendimiz anlatıyor ve arkadaşlarımızı öğrenci olarak görüyorduk. Orada eksikliklerimizi tespit ediyorduk. Ama tam olarak üniversitelerde verilmiyor." (Ö11)

Tablo 3 incelendiğinde sosyal bilgiler öğretmenlerinin bir kısmı (2 kişi) yapılandırmacılık konusunda eğitim almadıklarını ifade etmişlerdir. Bu katılımcılar mezun oldukları fakültenin eğitim fakültesi olmaması ve mezun oldukları dönemde ülkemizde henüz yapılandırmacı eğitimin uygulamaya konmamasını gerekçe olarak göstermişlerdir. Bu durumu Ö8 aşağıdaki şekilde ifade etmiştir:

"Böyle bir eğitim almadım. Fen-Edebiyat Fakültesi tarih bölümü mezunuyum. 1989 yılında mezun oldum. O zamanki şartlara göre böyleydi." (Ö8)

Katılımcılar üniversitede aldıkları eğitimle ilgili olarak, stajyerlik döneminde verilen eğitimin az ve niteliksiz olduğunu ifade etmişlerdir. Bu şekilde görüş belirten katılımcılar üniversite son sınıfta bu eğitimleri aldıklarını ancak ders anlatma, etkinlik yapma gibi hususlarda ya fırsat bulamadıklarını ya da çok az fırsat bulduklarını söylemişlerdir. Bu bağlamda katılımcılar stajyerlik eğitiminin daha önceki sınıflardan itibaren başlamasını ve uygulama öğretmenlerinin bu konuda yeterli olması gerektiğini ifade etmişlerdir. Bu durumu Ö10 şu şekilde dile getirmiştir:

“Aldığımız eğitim kitabi bilgileri almak oldu. Herhangi bir uygulama olmadı. Isste bunların staj döneminde iyi özümsenip iyi uygulanmass lazım. Okullarda buna yönelik öğretmenlerin stajyerine bilgiyi anlatması ve uygulatması lazım." (Ö10)

Lisans düzeyinde alınan eğitimde yapılandırmacı bir yaklaşım alıp almadıklarını ve almışlarsa niteliğini öğrenmeye yönelik soruya verilen cevaplardan biri ise katılımcıların yapılandırmacılığı sinavlar döneminde öğrenmeleridir. Bu şekilde görüş ifade eden katılımcılar, üniversitede yapılandırmacılık ile ilgili yöntem ve teknikleri derslerde işlediklerini; ancak hem yapılandırmacılık hem de yöntem ve tekniklerin mantığını KPSS'ye hazırlanma döneminde öğrendiklerini söylemişlerdir. Bu durumu Ö7 şu şekilde dile getirmiştir:

"KPSS sürecinde daha çok konu çalışırken işin içine girdik. O şekilde daha çok bilgilendim." (Ö7)

\subsection{Meslekte Çalışma Süresinin Yapılandırmacılığa Etkisine İlişkin Öğretmen Görüşleri}

Burada sosyal bilgiler öğretmenlerinin, meslekte çalışma süresinin yapılandırmacılığa etkisine ilişkin görüşlerine yer verilmiş, deneyimli veya mesleki kariyerin başlarında olmanın yapılandırmacılığa etkisi olup olmadığı, eğer varsa nasıl bir etkisi yaptığı ve nedenleri araştırılmaya çalışılmıştır. Sosyal bilgiler öğretmenlerinin meslekte çalışma süresinin yapılandırmacılığa etkisine dair görüşleri Tablo 4 'te gösterilmiştir. 
Tablo 4. Meslekte Çalışma Süresinin Yapılandırmacılı̆̆a Etkisine İlişkin Görüşler

\begin{tabular}{lc}
\hline Öğretmen Görüşleri & Frekans \\
\hline Deneyimli öğretmenler bu anlayışı uygulamaz & 9 \\
Yeni başlayan öğretmenler biliyor ama uygulayamıor & 4 \\
Bir zaman uyguladıktan sonra uygulamaktan vazgeçer & 3 \\
\hline
\end{tabular}

Tablo 4 incelendiğinde, katılımcıların meslekte çalışma süresinin yapılandırmacıllğa etkisinin dışında, bu anlayışın sürdürülememesi durumundan bahsettikleri görülmektedir. Tablo 4'e bakıldığında sosyal bilgiler öğretmenlerinin en çok vurguladığı husus, deneyimli öğretmenlerin yapılandırmacı anlayışı uygulayamadığı görüşü olmuştur. Bu doğrultuda görüş belirten katılımcılar; göreve yeni başlayan öğretmenlerin henüz bilgilerinin taze olması, daha istekli olması, güncel olan kavram, yöntem ve teknikleri iyi bilmesi gibi nedenlerle yapılandırmacılığı daha fazla uyguladıklarını ifade etmişlerdir. Sosyal bilgiler öğretmenleri, deneyimli öğretmenlerin ise bu anlayıştan haberi bile olmadığını ve klasik yöntemleri kullandıklarını belirtmişlerdir. Bu konuda Ö7'nin görüşleri şu şekildedir:

"Yeni başlayan öğretmenler bu anlayışı bildikleri için daha çok uyguluyorlar. Bu 10-20 yıllık gördü̈̆̈̈̈m öğretmenler zaten yeni yöntemlerden bihaber, kendi bildikleri klasik yöntemlerle devam ediyorlar." (Ö7)

Tablo 4 incelendiğinde katılımcıların ( 4 kişi) ifade ettiği diğer bir husus ise göreve yeni başlayan öğretmenlerin yapılandırmacılığı bilmesi fakat uygulayamamasıdır. Bu konuda görüş belirten katılımcılar, genç öğretmenlerin yapılandırmacılığı bildiğini fakat hayata geçiremediğini, uygulamaya geçirebilmesi için en az üç-beş yıl gerektiğini vurgulamışlardır. $\mathrm{Bu}$ durumun nedeni olarak ilk yıllarda üzerlerinde stajyerlik baskısı, mesleği öğrenme telaşı, zaman yönetimi ile diğer öğretmenlerin baskısı gibi durumların etkisini gerekçe göstermişlerdir. Bu konuda görüş belirten katılımcılardan bazılarının görüşleri şöyledir:

“Genellikle üniversiteden yeni mezun olmuş öğretmenler bu anlayışı çok iyi biliyor fakat uygulayamıyor, hayata geçiremiyor. Ancak bu anlayışı en iyi uygulayan öğretmenler 3-5 yıl arasında deneyime sahip olan öğretmenler gördüğ̈̈m kadarıla." (Ö13)

"İlk yılında öğretmen, öğretmenliği, sınıf yönetimini öğrendiği için açıkçası yapılandırmacılı̆̆ı uygulamaya vakti kalmıyor. Ayrıca stajyer öğretmen üzerinde diğer öğretmenlerin baskısı oluyor." (Ö5)

Katılımcılardan üç kişinin belirttiği başka bir husus ise öğretmenlerin yapılandırmacı anlayışı bir süre uygulayıp sonra vazgeçmesi ifadesi olmuştur. Bu konuda görüş belirten öğretmenler, mesleğe başladığı ilk yıllarda heves ve meslek aşkıyla birlikte üniversitede almış olduğu eğitim anlayışını etkili bir şekilde uyguladıklarını ancak sonraki yıllarda öğrencilerin ilgisiz olması, beklenen desteğin sağlanmaması ve çevresel koşulların etkisiyle uygulamaktan vazgeçip, klasik yöntemlerle dersini sürdürdüklerini ifade etmişlerdir. Bu durumu Ö4 aşağıdaki şu şekilde dile getirmiştir:

"Bence yeni atanan öğretmenler daha fazla uyguluyor. Şimdi bir meslek aşkı var, heyecan da var yeni atanan öğretmen çok daha fazla uyguluyor; ama bir iki yıl geçtikten sonra ne kadar kendini yorsan da eğer o çocuk algılamıyorsa ya da anlamak istemiyor çalışmıyorsa, devamın getirmiyorsa bu tekniklerden vazgeçiyorsun." (Ö4) 


\subsection{Sosyal Bilgiler Öğretmenlerinin Yapılandırmacılık Kapsamında Hizmet içi Eğitim Faaliyetlerine İlişkin Görüşleri}

Hizmet içi eğitimlerin sıklığı, öğretmenlerin bu seminerlere katılma durumu, eğer katılmışlarsa bu eğitimlerin ne derece yapılandırmacı anlayışa uygun olduğu araştırılmaya çalışılmıştır. Ülkemizde öğretmenlere mesleki gelişim anlamında verilen eğitim ve kursların yapılandırmacı anlayışa uygun bir şekilde yapılması öğretmenlerin yeni sistemi daha iyi özümsemesi ve onu sosyal bilgiler dersinde etkin bir şekilde kullanması için önemli bir durumdur. Hizmet içi eğitim faaliyetlerine dair sosyal bilgiler öğretmenlerinin görüşleri Tablo 5 'te gösterilmiştir.

Tablo 5. Hizmet içi Ĕ̆itim Faaliyetlerine İlişkin Görüşler

\begin{tabular}{lc}
\hline Öğretmen Görüşleri & Frekans \\
\hline Bu tarz eğitimlere katılmadım & 10 \\
Seminerler başarısız ve yetersiz & 5 \\
Yapılandırmacılıkla ilgili seminer verilmiyor & 5 \\
Bu konuda seminerlere katıldım & 4 \\
Kurs veren öğreticiler niteliksizdi & 3 \\
Bu eğitimler bize hiç duyurulmadı & 2 \\
Gitmeye niyetim yok & 2 \\
Uygulamalı ve zorunlu seminerler yapılmalı & 2 \\
Deneyimli öğretmenlere öncelik verilmeli & 1 \\
\hline
\end{tabular}

Tablo 5'e bakıldığında sosyal bilgiler öğretmenlerinin, hizmet içi eğitim faaliyetlerine katılma durumunun dışında, seminerlerin niteliğinden, eğiticilerin yeterlik düzeyinden ve eğitimlerin duyurulması durumlarından bahsettikleri görülmektedir.

Tablo 5 incelendiğinde katılımcıların büyük bir bölümü (10 kişi) bu tarz eğitimlere katılmadıklarını söylemişlerdir. Hizmet içi eğitimlere katılmadığını ifade eden katılımcılar, bulundukları bölgelerde yapılandırmacılığa dair eğitimlerin verilmediğini, yapılandırmacılık dişında hizmet içi eğitimlerin nispeten daha fazla olduğunu ancak o eğitimlerde de kursiyerlerin bir şey öğrenmek amacında olmayıp göstermelik olarak seminerlere katıldıklarını, bu nedenlerden dolayı kursları faydasız görüp eğitimlere katılmamaya karar verdiklerini ifade etmişlerdir. Bu konuda Ö10 ve Ö14'ün görüşleri şu şekildedir:

"Doğrudan yapılandırmacılık olmasa da bu yaklaşıma benzer bir kursa katıldım. Ancak hem kursa katılan öğretmenler kursa ilgisizdi hem de kursu veren kişilerin bu yöntemle alakası yoktu." (Ö10)

"Hayır katılmadım. Bu konuda problem çözme, bilimsel araştırma yöntemleri ile ilgili seminerler veriliyor. Yapılandırmacı anlayıs ile ilgili pek görmedim. Denk gelmedi bana." (Ö14)

Sosyal bilgiler öğretmenlerinin vurguladığı bir diğer husus ise seminerlerin başarısız ve yetersiz olduğudur. Bu bağlamda katılımcılar, hizmet içi eğitim faaliyetlerine katılan kursiyerlerin bu kurslara katılmaktaki amaçlarının yeni bir şeyler öğrenmek olmayıp nicelik olarak fazla sayıda seminere katılma durumu olması nedeniyle genellikle kursların bir an önce bitirildiğini, bu durumun ise kursların tam manasıyla başarıya ulaşmasını engellediğini ifade etmişlerdir. Bu konuda görüş belirten katılımcılardan bazılarının görüşü şöyledir: 
"Hayır katılmadım. Çünkü bizim ülkemizde maalesef hizmet içi eŏitim çok çok başarısız. Üç - dört farklı alanda katıldım. Herkes 'bitsin de gidelim' anlayışında olduğu için hiçbir verim alamadım ve bu tarz kurslara katılmama kararı aldım." (Ö6)

"Çünkü mahallî olarak yapılan seminerler genelde başarısız seminerler olduğu için gitme gereği duymadım açıkçası." (Ö1)

Katılımcıların en sık dile getirdiği durumlardan biri de yapılandırmacılıkla ilgili seminerler verilmediğidir (5 kişi). Bu doğrultuda görüş bildiren katılımcılar, çevresinde öğrencilerin aktif olmasını sağlayacak yöntem ve teknikleri içeren yapılandırmacı anlayışa uygun mahalli düzeyde başarılı seminerler verilmediğini, bu tarz verilen seminerlerin ise daha çok merkezi hizmet içi eğitim faaliyeti şeklinde gerçekleştirildiğini, bulunduğu bölgede bu eğitimlerin verilmesi durumunda katılmak istediklerini ve faydalı olacağını ifade etmişlerdir. Bu konuda görüş belirten Ö12'nin görüşleri şu şekildedir:

"Hayır katılmadım. Bildĭgim kadarıla böyle bir eğitim de olmadı. Olsa elbette ki katılırdım. Gerçekten verilen eğitim öğretici bir eğitimse, öğretmene bir bakış açısı kazandırmak içinse tabi ki seve seve katılırım." (Ö12)

Yapılandırmacılık konusunda hizmet içi eğitimlere katıldığını söyleyen sosyal bilgiler öğretmenleri (4 kişi), tam olarak yapılandırmacılık olmasa da bu anlayışa uygun yöntem ve teknikleri içeren seminerlerin yapıldığını kendilerinin de bu eğitimlere katıldıklarını ancak eğitimi veren kişilerin alanında yetersiz olması nedeniyle kendilerine çok fazla bir şey katmadığını, bu durumun ise öğretmenlerin yapılandırmacılığa dair olumsuz bir algı geliştirerek, bu anlayışı sorgulamalarına neden olduğunu ifade etmişlerdir. Bu durumu Ö5 aşağıdaki şekilde ifade etmiştir:

"Evet, 1-2 tane direkt yapilandirmacilı olmasa da yöntem olarak yakın olan kursa katıldım. Ama bu kursları veren kişiler bu anlayıştan o kadar uzak kişilerdi ki bana hiçbir şey katmadığı gibi bu anlayışı sorgulamama neden oldu." (Ö5)

Ülkemizde yapılan hizmet içi eğitim faaliyetlerine ilişkin olarak katılımcıların görüşlerinden elde edilen çarpıcı bir sonuç ise uygulamalı ve zorunlu seminer yapılma önerisi olmuştur. Bu bağlamda görüş belirten katılımclar, eğitim - öğretim döneminin başında ve sonunda yapılan mesleki çalışmaların öğretmene bir şey katmadığını, bu dönemlerde yapılandırmacı anlayışla ilgili yöntem ve teknikleri içeren eğitimlerin öğretmenlere zorunlu ve uygulamalı bir şekilde verilmesinin bu anlayışın sosyal bilgiler derslerinde etkili bir şekilde kullanılmasında büyük öneme sahip olacağını ifade etmişlerdir. Bu durumu Ö7 şu şekilde dile getirmiştir:

"Bunun bence seçmeli seminer değil de zorunlu olarak, okul başladı̆̆ı dönemde bunun uygulamalı olarak tüm ülkede bütün öğretmenlere verilmesi gerekiyor." (Ö7)

\section{SONUÇ, TARTIŞMA ve ÖNERİLER}

Araştırma sonucunda sosyal bilgiler öğretmenlerinin yapılandırmacılık konusunda öz yeterlik algısının olumsuz olduğu görülmüştür. Başka bir ifadeyle katılımcı öğretmenlerin yapılandırmacılık konusunda tam manasıyla kendini yeterli hissetmediği, yeterli hale gelmek için arayışlarda bulunduğu, bazı durumlarda kendilerini geliştirmeye fursat buldukları ancak genel itibariyle çevresel koşullar (veli, medya) ve kendilerinden kaynaklanan (yenilikleri takip edememe) nedenlerle bu konuda başarısız oldukları sonucuna ulaşılmıştır. Çalışmada öğretmenlerin yapılandırmacı eğitim ortamı oluşturma, konularla ve 
kazanımlarla ilgili yapılandırmacı yöntem ve teknikler uygulama konularında kendilerini yeterli hissetmedikleri görülmektedir. Karaca (2017)'nın “Ortaokullarda Görev Yapan Sosyal Bilgiler Öğretmenlerinin Sosyal Bilgiler Öğretiminde Karşılaştıkları Sorunlar ve Çözüm Önerileri" isimli çalışmasında da bu konuyla ilgili benzer sonuçlara ulaşılmıştır. Karaca (2017)'ya göre sosyal bilgiler öğretmenleri yapılandırmacı yöntem ve teknikler konusunda kendilerinin yeterli olduklarını düşünmemektedir. Ayrıca Yener (2014) yapmış olduğu araştırmada sosyal bilgiler öğretmenlerinin değişen ve gelişen dünyaya ayak uyduramadığı, bilimsel araştırmaları takip edemediği, kendilerini yenileyemediği ve bu durumun ise etkili sosyal bilgiler eğitimini olumsuz etkilediği sonucuna ulaşmıştır. Akşit (2011) yılında yapmış olduğu araştırmada sosyal bilgiler öğretmenlerinin yapılandırmacı yöntem ve teknikler konusunda bilgi sahibi oldukları ancak bu etkinlikleri kısmen uygulayabildikleri saptanmıştır. Yurt dişında Slovenya'da 181 sosyal bilgiler öğretmeni ile yapılan çalışmada öğretmenlerin yarıdan fazlasının (\%51.4) öğretmen merkezli geleneksel yöntemleri kullandıklarını göstermiştir (Jancic ve Hus, 2017, s.8).

Farklı branştaki öğretmenlerle yapılan çalışmalarda yapılandırmacı yaklaşım konusunda kendisini yeterli hisseden öğretmenlerin çoğunlukta olduğu görüşmüştür. Araştırmanın bu sonucunu desteklenmeyen çalışmalar olduğu da görülmektedir. Gömleksiz (2005), Ağlagül (2009), Fidan ve Duman (2014) sınıf öğretmenleriyle yapmış oldukları çalışmalarda öğretmenlerin yapılandırmacılık konusunda kendilerini yeterli gördükleri sonucunu elde etmiştir. Ayrıca Demir vd.(2012), fen bilimleri öğretmenleri ile yapmış olduğu çalışmada fen bilimleri öğretmenlerinin öz yeterlik algısının güçlü olduğunu tespit etmiştir. Eskici ve Özen (2018), yapmış oldukları çalışmada sınıf öğretmenlerin yapılandırmacılık konusunda öz yeterlilik algılarının yüksek olduğu sonucuna ulaşmıştır.

Araştırmada öğretmen yetiştirmeye kaynaklık eden fakültelerin öğretmen yetiştirme konusunda yetersiz olduğu, genel olarak öğretim elemanlarının yapılandırmacı yöntem ve teknikleri teorik bir şekilde aktarıp, uygulama konusunda çok fazla etkinliklere yer vermediği, katılımcıların yapılandırmacılığı KPSS'ye hazırlık döneminde öğrendikleri ve staj eğitiminin yeterli olmadığı sonucuna ulaşılmıştır. Bu konuda yapılan çalışmalarda benzer sonuçlar elde edilmiştir. Teotia (2017) yapılandırmacılık konusunda yapmış olduğu çalışmanın sonucu elde edilen bu bulguyu destekler durumdadır. Yener (2014), yapmış olduğu çalışmada sosyal bilgiler öğretmenlerinin mezun oldukları okullarda yöntem, teknik ile ilgili uygulamalı çalışmaların yetersiz olduğu sonucuna ulaşmıştır. Tahiroğlu (2016) yaptığı çalışmada öğretmenlerin üniversitede gerekli olan becerileri tam manasıyla öğrenemedikleri sonucunu elde etmiştir.

Araştırmamızda meslekteki çalışma süresinin yapılandırmacı anlayışın uygulanmasını olumsuz etkilediği sonucu elde edilmiştir. Katılımcıların ifadelerinden, mesleki deneyim süresi fazla olan sosyal bilgiler öğretmenlerinin, öğrencilerin sürece katılmasını sağlayacak yöntem ve teknikleri kullanmadıkları; göreve yeni başlayan sosyal bilgiler öğretmenlerinin ise bu yöntemleri daha fazla kullandıkları sonucuna ulaşılmıştır. Bu konuda yapılmış bazı çalışmalarda benzer sonuçlar elde edilmiştir. Akmehmetoğlu (2014) sosyal bilgiler, Aykan (2014) ortaokul öğretmenleri, Özdemir ve Kıroğlu (2011) sınıf öğretmenleriyle yapmış oldukları çalışmalarda mesleki deneyimi daha az olan öğretmenlerin yapılandırmacı yaklaşımı daha fazla uyguladıkları sonucuna ulaşmıştır. 
Bu konuda Özmen (2003), Gömleksiz (2007) fen bilimleri, Dündar (2008) sosyal bilgiler, Karadağ vd., (2008), Ağlagül (2009) sınıf öğretmenleriyle yapmış olduğu çalışmalarda farklı sonuçlar tespit edilmiş olup deneyimli öğretmenlerin yapılandırmacı anlayışı uygulama düzeylerinin daha yüksek olduğu sonucuna ulaşılmıştır. Yılmaz (2006) fen bilimleri, Fidan ve Duman (2014) sınıf öğretmenleri, Jancic ve Hus (2017) sosyal bilgiler öğretmenleriyle yapmış oldukları çalışmalarda ise mesleki kıdemin yapılandırmacı anlayışı uygulama konusunda herhangi bir etkisinin olmadığı görülmüştür.

Çalışmada ele alınan bir başka problem durumu ise öğretmenlerin öz yeterlik algılarına etki etme potansiyeli nedeniyle hizmet içi eğitim faaliyetlerine ilişkin görüşleriydi. Araştırmada öğretmenlerin büyük bir bölümünün hizmet içi eğitim faaliyetlerine katılmadığı, yapılandırmacılığa uygun ve uygulamaya dayalı eğitimlerin verilmediği, kursların başarısız ve öğreticilerin alanında yetersiz olduğu sonucuna ulaşılmıştır. Sosyal bilgiler öğretmenleri bu seminerlerin kaliteli olmadığını ve amaca hizmet etmediğini bundan dolayı da katılmak istemediklerini belirtmiştir. Yener (2014)'in "Sosyal Bilgiler Öğretmenlerinin Sosyal Bilgiler Öğretiminde Karşılaştıkları Sorunlara İlişkin Öğretmen Görüşleri, Muş Il Örneği" adlı araştırmasında da bu konuyla ilgili benzer sonuçlara ulaşılmıştır. Yener (2014) yapmış olduğu çalışmada, hizmet içi eğitim kurslarının yetersiz olduğu ve bu kurslarda sosyal bilgiler öğretmenlerine eğitimde kullanılan araç gereçleri ve yöntem, teknikleri tanıma ve uygulama fırsatı verilmediği, bu durumun ise öğretmenlerin yeni durum, yöntem ve tekniklere uyum sağlamasını zorlaştırdığı, öğretmenleri tam manasıyla yetiştiremediği sonucuna ulaşmıştır. Yine Karadağ vd. (2008) araştırmalarında hizmet içi eğitim faaliyetlerinin uygulamalı bir şekilde yapılmamasının, öğretmenlerin yapılandırmacı faaliyetleri öğrenmesini de olumsuz etkilediğini saptamışlardır. Tahiroğlu (2016) yaptığı çalışmada sosyal bilgiler öğretmenlerinin hizmet içi eğitimlere yeterince katılamadıklarını, kendilerini yeterince geliştiremediklerini tespit etmiştir.

Bulgular ve tartışma dikkate alındığında sosyal bilgiler öğretmenlerinin yapılandırmacı yaklaşım konusunda öz yeterlik algılarının düşük olduğu anlaşılmaktadır. Bunda hizmet öncesi yani lisans döneminde alınan eğitimlerin yetersizliği, göreve başladıktan sonra öğretmenlere kendilerini geliştirecek yeterli hizmet içi eğitim imkânların sunulmaması, verilen hizmet içi eğitimlerin ise amaca uygun olmaktan uzaklığı önemli rol oynamaktadır. Öte yandan iyi eğitim alarak göreve başlayan öğretmenlerden bir kısmının ise zaman içerisinde öğrenci ilgisizliği, meslektaş baskısı ve iş yoğunluğu gibi nedenlerle heveslerinin kırılarak uygulamaktan vazgeçtikleri anlaşılmaktadır.

Yapılan bu çalışma örneklem sayısının az olduğu nitel bir çalışmadır. Konu ile ilgili daha fazla örneklemin çalışmaya dâhil edildiği nicel bir çalışma yapılabilir. Yapılan bu çalışmada sosyal bilgiler öğretmenlerinin özellikle üniversite eğitimi konusunda teorik çalışmaların yapıldığ uygulamalı çalışmalara yer verilmediği sonucundan hareketle sosyal bilgiler öğretmenliği üniversite eğitimi gören öğrencilerle üniversitede verilen eğitimin yapılandırmacılığa uygunluğu konusunda çalışma yapılabilir. Yapılan bu çalışmada öğretmenlerin hizmet içi eğitim konusunda olumsuz tutuma sahip oldukları görülmüştür. Bu olumsuz tutumların nedenleri ayrıntılı bir şekilde incelenebilir. Meslekteki çalışma süresinin modern yöntem ve tekniklere etkisi ile ilgili bir çalışma yapılabilir. Hizmet içi eğitim, konferans, çalıştay ve sempozyum çalışmalarının yapılandırmacı anlayışa uygunluğu ile ilgili diğer branş öğretmenlerinin de dahil edildiği bir çalışma yapılabilir. 


\section{KAYNAKÇA}

Ağlagül, D. (2009). Beşinci sınıf sosyal bilgiler dersinde sını öğretmenlerinin yapılandırmacı öğrenme ortamı düzenleme becerilerinin değerlendirilmesi. Yayımlanmamış yüksek lisans tezi, Çukurova Üniversitesi, Adana.

Akçamete, A.G. (2005). Öğretmen yetiştirme sorunları çalıştayı. Ankara: Ankara Üniversitesi Eğitim Bilimleri Fakültesi, Tekışık Eğitim Araştırma Geliştirme Vakfı.

Akdağ, H., Turan, R. ve Sünbül, A. M. (2009). Sosyal bilgiler öğretiminde yeni yaklaşımlar-1: Sosyal bilgilerin tanımı, amacı, önemi ve Türkiye'deki yeri. Ankara: Pegem Akademi.

Akdeniz, N. (2008). Altıncı sınıf sosyal bilgiler ders programının uygulanmasında karşılaşılan güçlükler. Yayımlanmamış yüksek lisans tezi, Selçuk Üniversitesi, Konya.

Akmehmetoğlu, H. (2014). Sosyal bilgiler öğretmenlerinin sosyal bilgiler öğretiminde karşılaştıkları sorunlar (Kastamonu İli Örneği. Yayımlanmamış yüksek lisans tezi, Kastamonu.

Akşit, İ. (2011). İlköğretimde görev yapan sosyal bilgiler öğretmenlerinin sosyal bilgiler öğretiminde karşılaştıkları sorunlar (Denizli ve Erzurum İli Örneği). Yayımlanmamış yüksek lisans tezi, Pamukkale Üniversitesi, Denizli.

Arslantaş, S. (2006). 6. ve 7. sinfflarda sosyal bilgiler dersi program uygulamalarında karşılaşılan sorunların öğretmen görüşleri açısından incelenmesi (Malatya ili örneği). Yayınlanmamış yüksek lisans tezi, Fırat Üniversitesi, Elazığ.

Aydın, H. (2000). Öğrenme ve öğretme kuramlarının eğitim iletişimine katkısı. Kurgu Dergisi, 14, 183-197.

Aydın, N. (2008). Sını öğretmeni adaylarının ve öğretmenlerinin çevre eğitimine yönelik öz yeterlik inançları üzerine sınıf düzeyi, kıdem ve değer yönelimlerinin etkisi. Yayınlanmamış yüksek lisans tezi, Adnan Menderes Üniversitesi, Aydın.

Aykan, A. (2014), Ortaokul öğretmenlerinin yapılandırmacı yaklaşım ile ilgili yeterlik düzeylerinin incelenmesi. Yayımlanmamış yüksek lisans tezi, Yüzüncü Yıl Üniversitesi, Van.

Bahar, H. (2007). Immanuel Kant ve eğitim üzerine. Ata, B., Bağcl, Ş. (Ed.). Sosyal bilgiler eğitimi açısından eğitim klasikleri incelemeler içinde. (Birinci Baskı). Ankara: Pegema Yayıncilik.

Bada, M. (2018). Sosyal bilgiler öğretmenlerinin yapılandırmacı eğitim yaklaşımına ilişkin görüşleri. Yayımlanmamış yüksek lisans tezi, Erciyes Üniversitesi, Kayseri.

Bandura, A. (1986). Social foundations of thought and action; A social cognitive theory. New Jersey: Englewood Cliffs Prentice Hall.

Demir, S., Önen, F., ve Şahin, F. (2012). Fen bilgisi öğretmen adaylarının yapılandırmacı yaklaşımı uygulamaya yönelik öz yeterlilik inanç düzeylerinin belirlenmesi üzerine bir araştırma. X. Ulusal Fen Bilimleri ve Matematik Ĕ̆itimi Kongresi, 27-30.

Dilaver, H. H. ve Akyürek Tay, B. (2011). Sosyal bilgilerde yapılandırmacılı; Özel öğretim yöntemleriyle sosyal bilgiler öğretimi. Ankara: Pegem Akademi.

Doğanay, A. (2005). Öğretimde kavram ve genellemelerin geliştirilmesi. Öztürk, C., Dilek, D. (Ed.). Hayat bilgisi ve sosyal bilgiler öğretimi İçinde. Ankara: Pegem A Yayıncilık. 
Dündar, Ş. (2008). İlköğretim sosyal bilgiler dersi öğrenme ortamlarının yapılandırmacı özellikler açısından değerlendirilmesi. Yayınlanmamış yüksek lisans tezi, Marmara Üniversitesi, İstanbul.

Erden, M. ve Akman, Y. (2001). Gelişim öğrenme-öğretme. (10. Baskı). Ankara: Arkadaş Yayınevi.

Eskici, M. ve Özen, R. (2013). Öğretmenlerin yapılandırmacı yaklaşımı uygulamaya yönelik tutum ölçeği. Elektronik Eğitim Bilimleri Dergisi, 2(4), 74-87.

Fidan, N. ve Duman, T. (2014). Sınıf öğretmenlerinin yapılandırmacı yaklaşımın gerektirdiği niteliklere sahip olma düzeyleri. Eğitim ve Bilim Dergisi, 39(174), 143-159.

Gömleksiz, M. N. (2007). Yeni ilköğretim programına ilişkin öğretmen görüşlerinin çeşitli değişkenler açısından değerlendirilmesi. Euraian Journal of Educational Research, 27, 6982.

Jadallah, E. (2000). Constructivist learning experience for social studies education. The Social Studies, 91(5), 221-225.

Jancic, P.ve Hus, V. (2000). Teachers' attitudes toward constructivist teaching of social studies in primary schools (with the emphasis on learning forms), International Journal of Researc in Engineering and Techology, EISSS, 2319-1163.

Karaca, S. (2017). Ortaokullarda görevli sosyal bilgiler öğretmenlerinin Sosyal bilgiler öğretiminde karşılaştıkları sorunlar (Çorum ili örneği). Yayımlanmamış yüksek lisans tezi, Amasya Üniversitesi, Amasya.

Karacaoğlu, C.Ö. ve Acar, E. (2010). Yenilenen programların uygulanmasında öğretmenlerin karşılaştıkları sorunlar. Yüzüncü Yıl Üniversitesi Eğitim Fakültesi Dergisi, 7(1), 45-58.

Karadağ, E. vd. (2008). Yapılandırmacı öğrenme yaklaşımı: Sınıf öğretmenleri görüşleri kapsamında bir araştırma. Uludă̆ Üniversitesi Ĕ̆gitim Fakültesi Dergisi, XXI(2), 383-402.

Kıroğlu, K. (2011). İlköğretim programları (1-5. simıflar). Ankara: Pegem Akademi Yayıncılık.

Kısakürek, M. A. (1988). Sosyal bilgiler öğretiminin niteliği, kapsamı ve amaçları. Sosyal bilgiler öğretimi. Eskişehir: T.C. Anadolu Üniversitesi Yayınları.

Kumar, A. ve Teotia, A. (2017). Constructivism: A dynamic approach of teachinglearning social science at upper primary level. International Journal of Management and Applied Science, 3(5), 2394-7936.

Mohammed, Husam, S. ve Kinyo, L. (2020), The role of constructivism in the enhancement of social studies education. Journal of Critical Reviews, 7(7), 2394-5125.

Mutlu, N. ve Öztürk M. (2017). Sosyal bilgiler ve tarih derslerinde farklılaştırılmış öğretime yönelik öğretmen algıları ve uygulamaları. Trakya Üniversitesi Eğitim Fakültesi Dergisi, 7(2), 379-402.

Özden, Y. (2003). Öğrenme ve öğretme. (5. Basım). Ankara: Pegem A Yayıncılık.

Özden, Y. (2011). Öğrenme ve öğretme. Ankara: Pegem Akademi Yayınları. 
Özmen, Ş.G. (2003). Fen bilgisi öğretmenlerinin yapılandırmacı öğrenme yaklaşımına ilişkin görüşlerinin incelenmesi. Yayınlanmamış yüksek lisans tezi, Hacettepe Üniversitesi, Ankara.

Sağlamer, E. (1983). Sosyal bilgiler öğretimi. Ankara: Tekışık Matbaası Yayınları.

Scheurman, G. (1998). From behaviourist to constructivist teaching. Social Education, 62(1), 6-9.

Şimşek, N. (2004). Yapılandırmacı öğrenme ve öğretime eleştirel bir yaklaşım. Eğitim Bilimleri ve Uygulama, 3(2), 115-139.

Tahiroğlu, M. (2006). İlköğretim okulları ikinci kademesinde sosyal bilgiler dersi öğretmenlerinin sosyal bilgiler dersi öğretiminde karşılaştıkları güçlükler. Yayınlanmamış yüksek lisans tezi, Selçuk Üniversitesi, Konya.

Teague, R. (2000), Social constructivism \& social studies. Retrieved Agust, 29, 2-13.

Timur, Ş. (2020). Sosyal bilgiler öğretmenlerinin çevre eğitimi öz-yeterlik düzeylerinin incelenmesi (Sakarya örneği). Yayınlanmamış yüksek lisans tezi, Aksaray Üniversitesi, Aksaray.

Ünlü, İ., Koçoğlu, E. ve Ay, A. (2015). Sosyal bilgiler lisans programındaki uygulamaya yönelik öğretmen adayı görüşlerinin incelenmesi. Mediterranean Journal of Humanities, 5(1), 371-386.

Yaşar, Ş. ve Gürdoğan B., Ö. (2010). İlköğretim 5. sınıf öğrencilerinin bakış açısıyla sosyal bilgiler. 9.Ulusal sınıföğretmenliği eğitimi sempozyumu, 20- 22 Mayıs 2010, Elazığ.

Yener, Ş. (2014). Sosyal bilgiler öğretmenlerinin sosyal bilgiler öğretiminde karşılaştıkları sorunlara ilişkin öğretmen görüşleri: Muş il örneği. Yayınlanmamış yüksek lisans tezi, Atatürk Üniversitesi, Erzurum.

Yıldırım, A. ve Şimşek, H. (2008). Sosyal bilimlerde nitel araştırma yöntemleri. (6. Baskı). Ankara: Seçkin Yayıncılık.

Yıldırım, A. ve Şimşek H. (2011). Sosyal bilimlerde nitel araştırma yöntemleri. Ankara: Seçkin Yayıncilik.

Y1lmaz, B. (2006). Beşinci sınıf öğretmenlerinin fen ve teknoloji dersinde yapılandırmacı öğrenme ortamı düzenleme becerileri. Yayınlanmamış yüksek lisans tezi, Yıldız Teknik Üniversitesi, İstanbul. 